\title{
Maria dos Prazeres e Noi: à margem
}

\author{
Maria dos Prazeres and Noi: marginalized \\ Bethânia Martins Mariano \\ Universidade Federal de Uberlândia - Uberlândia, MG, Brasil
}

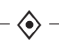

\begin{abstract}
Resumo: Espantada com um sonho que teve, que segundo sua interpretação o veredito era de que sua morte estava próxima, Maria dos Prazeres, uma prostituta idosa, brasileira, que mora na Espanha desde jovem, cuida dos detalhes de seu sepultamento e treina seu cachorro Noi para ir visitá-la no túmulo e chorar por ela quando ela finalmente partir. "Maria dos Prazeres" é o sétimo conto da obra Doze contos peregrinos, de Gabriel García Márquez. Nesta obra podemos verificar que as personagens principais são latino-americanas e se encontram, por alguma circunstância, solitárias na Europa, sofrendo alguma desventura, peregrinando entre o velho e novo mundo. A proposta deste artigo é ler este conto considerando que as literaturas que florescem no subdesenvolvimento cultural adquirem lentamente a consciência nacional e universal, apresentando um olhar da margem, excêntrico, e então as literaturas latino-americanas deslocam-se das tradições europeias.
\end{abstract}

Palavras-chave: Literatura fantástica; Insólito; Real maravilhoso; América Latina

\begin{abstract}
Maria dos Prazeres is a Brazilian elderly prostitute who lives in Spain since she was very young. Once, she had a dream and according to her interpretation the verdict was that her death was coming soon. Due to this dream, she takes care of her burial details and trains her dog, Noi, to visit her in her grave and cry for her when she is finally gone. "Maria dos Prazeres" is the seventh tale of Strange pilgrims, from the Colombian writer Gabriel García Márquez. In this book we realize the main characters are Latin-Americans and, for some circumstance, they are solitary in Europe, suffering misadventures, roaming between the New and Old World. The purpose of this paper is to read the mentioned tale considering that the literatures that flourish in cultural underdevelopment slowly acquire national and universal consciousness, presenting a marginalized, eccentric view. Therefore, Latin-American literatures dislocate themselves from European traditions.
\end{abstract}

Keywords: Fantastic literature; Uncanny; Marvelous real; Latin America

Mas que será toda a história da América senão uma crônica do real-maravilhoso?

(CARPENTIER, 2009, p. 12)

Tzvetan Todorov (2004), em sua obra intitulada Introdução à literatura fantástica, organizou, reuniu e discutiu estudos anteriores sobre a literatura que tem o insólito em sua trama. Sua perspectiva teórica agrupou formas similares e apartou formas diferentes de trabalho com o sobrenatural, organizando, assim, as variadas formas da narrativa fantástica em "gêneros", de maneira ainda estruturalista.

Segundo Todorov (2004), o fantástico, o estranho e o maravilhoso são gêneros vizinhos.
Para esse teórico, nós, leitores, somos transportados para o âmago do fantástico na situação em que, pisando no solo de um mundo que conhecemos, um mundo prosaico às nossas vivências, sem anjos, demônios ou monstros, vemo-nos diante de um acontecimento impossível de esclarecer pelas leis desse mundo familiar. E, então, temos duas opções pela frente: ou tal acontecimento é fruto da nossa imaginação, uma ilusão dos nossos sentidos, ou o acontecimento integra a nossa realidade, contudo esta é regida por leis que ignoramos (GAMA-KHALIL, 2013, p. 20). 
As narrativas do gênero estranho frequentemente provocam o medo e muitas narrativas de horror poderiam ser englobadas nesse gênero. No estranho, ainda para Todorov (2004), há fatos incríveis e inquietantes, mas que podem ser esclarecidos pela lógica e razão. Estes fatos podem causar nas personagens e no leitor reações semelhantes à das narrativas fantásticas, no entanto, como são possíveis explicações racionais para os fatos supostamente sobrenaturais, já não se trata do gênero literatura fantástica.

Já nas narrativas do gênero maravilhoso, de acordo com Todorov (2004), os acontecimentos supostamente sobrenaturais não provocam hesitação nas personagens e nos leitores, eles encontram-se naturalizados no mundo da narrativa. Podemos tomar os contos de fada como exemplo do gênero maravilhoso, "porque neles varas de condão, lobos que falam, botas mágicas são naturais àquele mundo ficcional" (GAMA-KHALIL, 2013, p. 21). Por não provocar hesitação nas personagens e nos leitores, Todorov separa essas narrativas das que pertencem ao gênero fantástico.

"A fé absoluta como a incredulidade total nos levam para fora do fantástico; é a hesitação que lhe dá a vida." (TODOROV, 2004, p. 36). Para Todorov, então, a hesitação, presente no plano da narrativa e no da recepção, é uma condição primordial para a existência do fantástico. De acordo com Gama-Khalil (2013, p. 22), a hesitação

caracteriza o discurso amplamente metafórico instituído pela literatura fantástica, pois nela os planos da imaginação e da conotação suplantam o da realidade, fazendo com que o receptor movimente sua interpretação, no sentido de questionar o conceito da realidade que tem em seu entorno.

Filipe Furtado, teórico português fortemente influenciado por Todorov, em sua obra $A$ construção do fantástico na narrativa, busca deslocar a noção de hesitação proposta por Todorov. Para Furtado (1980), na literatura do sobrenatural há o elemento meta-empírico, para além do empírico, e a constatação desse elemento leva à ambiguidade. Assim como na teoria proposta por Todorov, para Furtado no gênero maravilhoso não há ambiguidade, no gênero estranho há ambiguidade, mas ela não permanece na narrativa, visto que se desfaz por argumentos da lógica, e somente no gênero fantástico a ambiguidade se mantém. A diferença que Furtado estabelece perante a teoria de Todorov é a de que "a permanência da ambiguidade é uma questão interna à narrativa, ao passo que, para Todorov, a hesitação estaria também condicionada à recepção do acontecimento insólito." (GAMA-KHALIL, 2013, p. 24).

$\mathrm{Na}$ perspectiva genológica, quando as diferenças entre os gêneros são mais enfatizadas, limites são definidos entre o gênero fantástico e os gêneros vizinhos. $\mathrm{Na}$ perspectiva modal temos o modo fantástico, onde, em outra linha de entendimento, teóricos buscam compreender essa literatura não privilegiando as diferenças, mas, agrupando-a por semelhanças. Dessa forma, o modo fantástico engloba narrativas que não se encaixariam no gênero fantástico proposto por Todorov (GAMA-KHALIL, 2013, p. 19).

Irène Bessière, Rosemary Jackson, Remo Ceserani e Italo Calvino são teóricos que se debruçaram sobre a falibilidade da noção de gênero para a definição da literatura fantástica. De acordo com Gama-Khalil (2013, p. 25), essa perspectiva genológica limita a diversidade de obras "construídas a partir de variadas formas de trabalho que surpreendem ou contrariam o leitor. O fantástico se planteia, então, como um modo, que se constitui por intermédio de formas e temáticas cujo fito é incitar a incerteza."

Filipe Furtado, pois, fundamentado principalmente pelo estudo de Rosemary Jackson, escreve o verbete "Fantástico (Modo)" para o E-dicionário de termos literários de Carlos Ceia, e assim "mostra aos leitores que a literatura fantástica pode ser mais bem compreendida se mirada pela perspectiva modal." (GAMA-KHALIL, 2013:28). Nesse verbete ele declara que o modo fantástico abrange obras de arte e obras literárias que, longe de se pretenderem realistas, recusam "atribuir qualquer prioridade a uma representação rigorosamente "mimética" do mundo objectivo" (FURTADO, 2017, p. 1).

Fizemos essa breve exposição de alguns preceitos teóricos que concernem à literatura fantástica a fim de situar o leitor em relação a nossa escolha teórica e metodológica para analisar o conto "Maria dos Prazeres", presente na obra Doze contos peregrinos, do escritor colombiano Gabriel García Márquez. Entendemos que essa narrativa se encontra dentro das premissas do modo fantástico.

"Maria dos Prazeres" é o sétimo de doze contos selecionados para a obra que foi publicada em 1992 com contos que foram escritos e reescritos durante dezoito anos, peregrinando dentro das mochilas dos filhos de Márquez nas viagens de família e também da mesa do escritor para o cesto de lixo, como ele nos conta no prólogo do livro. Nos doze contos selecionados para a obra, podemos verificar que as personagens principais são latino-americanas e se encontram, por alguma circunstância, solitárias na Europa, sofrendo alguma desventura, peregrinando entre o velho e novo mundo.

Maria dos Prazeres é uma prostituta de 76 anos, brasileira, que está na Catalunha - Espanha há mais de cinquenta anos. Sobre Maria dos Prazeres, o narrador do conto nos revela que: 
Falava um catalão perfeito com uma pureza um pouco arcaica, embora ainda se notasse a música de seu português esquecido. Apesar de seus anos e de seus cachos de arame continuava sendo uma mulata esbelta e vivaz, de cabelo duro e olhos amarelos e ferozes, e já fazia muito tempo que havia perdido a compaixão pelos homens (MÁRQUEZ, 1992, p. 138).

Ela está na Catalunha desde tão nova pois sua mãe a vendera aos quatorze anos no porto de Manaus e "o primeiro-oficial de um barco turco desfrutou dela sem piedade durante a travessia do Atlântico e depois deixou-a abandonada e sem dinheiro, sem idioma e sem nome no pântano de luzes do Paralelo." (MÁRQUEZ, 1992, p. 150-151). Após sofrer tamanha violência, Maria dos Prazeres tornou-se prostituta, e, já na velhice, no bordel onde trabalhou sua vida inteira a declararam "usada demais para os gostos modernos e quiseram mandá-la para uma casa de aposentadas clandestinas que por cinco pesetas ensinavam os meninos a fazer amor." (MÁRQUEZ, 1992, p. 150).

No início do conto, um homem da agência funerária chega até a casa de Maria tão pontualmente que ele ainda estava de roupão de banho e com bobes na cabeça, então ela colocou uma rosa vermelha na orelha para não parecer tão indesejável como se sentia. Ao abrir a porta e ver que não era um tabelião lúgubre, como supunha que eram os comerciantes da morte, mas, um jovem tímido com um paletó quadriculado e gravata com pássaros coloridos, lamentou ainda mais sua situação.

Maria dos Prazeres, que havia recebido tantos homens a qualquer hora, sentiu-se envergonhada como muito poucas vezes. Acabava de completar 76 anos e estava convencida de que ia morrer antes do Natal, e ainda assim esteve a ponto de fechar a porta e pedir ao vendedor de enterros que esperasse um instante enquanto se vestia para recebê-lo de acordo com seus méritos. Mas depois pensou que ele iria congelar no vestíbulo escuro e o fez entrar.

- Perdoe essa cara de morcego - disse -, mas estou há mais de cinquenta anos na Catalunha e é a primeira vez que alguém chega na hora anunciada (MÁRQUEZ, 1992, p. 138).

O vendedor ficou a um passo da porta, pois, embora novo no ofício, sabia que não receberia aquela recepção festiva às oito da manhã, menos ainda de uma anciã que à primeira vista lhe pareceu "uma louca fugitiva das Américas.” (MÁRQUEZ, 1992, p. 138). Maria então abriu as grossas cortinas de pelúcia das janelas, e o "tênue resplendor de abril iluminou um pouco o ambiente meticuloso da sala que mais parecia a vitrine de um antiquário." (MÁRQUEZ, 1992, p. 138). Ao reparar que cada coisa estava cautelosamente colocada em seu devido lugar, coisas de gosto bastante certeiro, como se estivessem em seu espaço natural, o vendedor se desculpa, dizendo que enganou-se de porta. E Maria responde "- Oxalá - disse ela -, mas a morte não se engana.” (MÁRQUEZ, 1992, p. 139).

O agente funerário começou a mostrar, com um gráfico cheio de dobras, as parcelas de cores diversas e cruzes e cifras em cada cor. Ao compreender que aquele era o plano completo do imenso panteão de Montjuich, Maria lembrou

com um horror muito antigo do cemitério de Manaus debaixo dos aguaceiros de outubro, onde chafurdavam as antas entre os túmulos sem nomes e mausoléus de aventureiros com vitrais florentinos. Certa manhã, sendo muito menina, o Amazonas transbordado amanheceu convertido num pântano nauseabundo, e ela havia visto os ataúdes rachados flutuando no quintal da sua casa com pedaços de trapos e cabelos de mortos nas rachaduras. Aquela recordação era a causa de que tivesse escolhido o morro de Montjuich para descansar em paz, e não o pequeno cemitério de San Gervasio, tão próximo e familiar.

- Quero um lugar onde as águas não cheguem nunca - disse.

- Pois aqui está - disse o vendedor, indicando o lugar no mapa com um apontador extensível que levava no bolso como uma esferográfica de aço. - Não há mar que suba tanto (MÁRQUEZ, 1992, p. 139).

A partir do trecho acima, podemos perceber uma imagem terrível que marcou para sempre Maria dos Prazeres: a imagem da morte, dos caixões rachados, dos corpos finados, do horror à morte. As imagens de águas lúgubres são comumente encontradas nas obras de Gabriel García Márquez. Segundo Bachelard (1997, p.58), as imagens das águas escuras e sombrias

têm sua origem no mundo das imagens primordiais. Seguem o próprio princípio do sonho material. Suas águas preencheram uma função psicológica essencial: absorver as sombras, oferecer um túmulo cotidiano a tudo o que, diariamente, morre em nós. A água é assim um convite à morte; é um convite a uma morte especial que nos permite penetrar num dos refúgios materiais elementares.

Para Bachelard (1997), a água escura e pesada é um elemento material que recebe a morte em sua intimidade, e o destino das imagens da água segue exatamente o destino do devaneio da morte. Maria dos Prazeres, lembrando-se das águas fúnebres de Manaus, mesmo que as rejeitando e procurando um lugar onde possa ser enterrada sem que algo parecido aconteça, também se encaminha para a morte, o devaneio que permeia todo o conto. 
Procurando no tabuleiro de tumbas do vendedor, Maria dos Prazeres encontra a entrada principal, onde estavam as três tumbas contíguas, idênticas e sem nome,

onde jaziam Buenaventura Durruti e outros dois dirigentes anarquistas mortos na Guerra Civil. Todas as noites alguém escrevia os nomes nas lápides em branco. Escreviam com lápis, com tinta, com carvão, com lápis de sobrancelha ou esmalte de unhas, com todas as suas letras e na ordem correta, e todas as manhãs os zeladores os apagavam para que ninguém soubesse quem era quem debaixo dos mármores mudos. Maria dos Prazeres havia assistido ao enterro de Durruti, o mais triste e tumultuado de todos os que ocorreram em Barcelona, e queria repousar perto de sua tumba. Mas não havia nenhuma disponível no vasto panteão agora superpovoado (MÁRQUEZ, 1992, p. 140).

Compreendemos, a partir do trecho acima, que algumas pessoas tentam registrar que os cadáveres são dos anarquistas, em uma tentativa de manter essa memória, e outras tentam apagar esse fato, realmente apagando seus nomes das lápides incansavelmente, como se essa memória não tivesse existido, como se a memória pudesse ser apagada apenas com o gesto de limpar nomes de lápides. Podemos relacionar o trecho supracitado com a noção de arquivo para Foucault, pois o arquivo regula o que deve cair no esquecimento e o que deve ser considerado tradição. Conforme Simioni (2016, p. 179), para Foucault o arquivo é "o sistema de discursividade que separa o que merece ser arquivado como história e o que deve ser esquecido." E por quais razões esses anarquistas devem ser esquecidos?

Nesse momento da narrativa o autor faz uma referência a Boaventura Durruti, um anarco-sindicalista que lutou contra as forças fascistas do ditador General Franco, considerado o eterno ditador da Espanha, e outros dois dirigentes anarquistas. Candido (2009, p. 71) enfatiza que a personagem é um ser fictício, no entanto, as personagens podem ser construídas a partir de um modelo real, conhecido pelo escritor, que serve de eixo, ou ponto de partida para a invenção das mesmas. Consideramos que Durruti, aqui, é um ser de papel, uma criação ficcional, ainda que traga na narrativa a remissão a um nome de um ser "real" e à parte da história desse ser. A verossimilhança nas obras de ficção depende desse ser que, mesmo sendo uma criação da fantasia, comunica a impressão da verdade existencial válida. E a personagem é a concretização dessa relação entre o ser vivo e o ser fictício.

No entanto, consideramos que escolha dos nomes das personagens não é aleatória, visto que todo signo é ideológico. De acordo com Linda Hutcheon (1991, p. 143) a história e a ficção sempre foram conhecidas como gêneros permeáveis. A historicidade que os nomes das personagens carregam desencadeia sentidos na narrativa. As fronteiras elásticas entre história e ficção possibilitam que as personagens latino-americanos contem também $\mathrm{a}$ (s) história(s) da América Latina, reescrevendo o passado dentro de um novo contexto.

Maria dos Prazeres, que Márquez terminou de escrever em 1979, não é o único conto da obra que faz referência direta ao governo ditatorial do General Franco e à Guerra Civil que antecede a tomada de poder na Espanha. Na América Latina, o final da década de 70 é marcado por usurpações políticas, desmandos e violências empreendidas por regimes ditatoriais, principalmente no Brasil, Argentina e Chile. Segundo Vieira (2010, p. 129-130), "toda a violência cometida pelo regime franquista serve de plataforma para se falar daquilo que acontece com a América em meados das décadas de 70 e 80 do século XX: a violência dos regimes ditatoriais." Para esse autor, com quem concordamos, a Guerra Civil Espanhola é resgatada nos contos a fim de falar-nos também do tempo presente e do tempo da escrita dos contos dessa obra, comentar esse acontecimento histórico na Espanha é levantar questões sobre a América Latina atual.

Após saber que não seria possível que a enterrassem ao lado de Durruti, ela resignou-se com o possível. Colocou ao vendedor as condições de que não a colocassem dentro de gavetas, onde os corpos ficam como no correio, porém a enterrassem deitada, e que seu corpo repousasse à sombra das árvores no verão, em um lugar sem riscos de inundação. Enquanto ela e o vendedor conversavam sobre isso, "bateram na porta com três golpezinhos discretos, e ele fez uma pausa incerta, mas Maria dos Prazeres indicou que continuasse. - Não se preocupe - disse em voz muito baixa. - É o Noi." (MÁRQUEZ, 1992, p. 141).

Noi era o cãozinho de Maria dos Prazeres, que vivia com ela. Com a sua chegada, acontece um evento insólito na narrativa:

Abriu a porta da rua e entrou um cãozinho empapado pela chuvinha fina, e com um aspecto perdulário que não tinha nada a ver com o resto da casa. Regressava do seu passeio matinal pela vizinhança, e ao entrar sofreu um arrebato de alvoroço. Saltou sobre a mesa latindo sem sentido e quase estropiou o mapa do cemitério com as patas sujas de barro. Um único olhar da dona foi suficiente para moderar seus ímpetos.

- Noi! - disse a ele sem gritar. - Baixa d'ací!

O animal se encolheu, olhou-o assustado, e um par de lágrimas nítidas resvalou por seu focinho. Então Maria dos Prazeres tornou a se ocupar do vendedor e encontrou-o perplexo.

- Collons! - exclamou ele. - Chorou!

- É que ficou alvoroçado por encontrar alguém aqui a esta hora. - Em geral, entra na casa com mais cuidado que os homens. Exceto você, como já notei. 
- Mas ele chorou, caralho! - repetiu o vendedor, e de imediato percebeu a sua incorreção e desculpou-se, ruborizado: - A senhora me perdoe, mas é que não vi isto nem no cinema.

- Todos os cães podem fazer isso se forem ensinados - disse ela. - Acontece que os donos passam a vida educando os cachorros com hábitos que os fazem sofrer, como comer em pratos ou fazer suas porcarias na hora certa e no mesmo lugar. E, em compensação, não ensinam as coisas naturais das quais eles gostam, como rir e chorar. Mas aonde estávamos? (MÁRQUEZ, 1992, p. 141-142).

A partir desse trecho da narrativa, entendemos este conto como pertencente ao modo fantástico do qual nos fala Furtado, tendo em vista que a manifestação do insólito deve-se à falta de explicação que um fato encontra na época de produção do texto. Hoje, anos depois da publicação do conto, ainda não encontramos explicação para o fato de um cachorro chorar e rir como um humano. A aparição do cachorro instaura a hesitação, a ambiguidade, a incerteza, a ambivalência.

Lenira Marques Covizzi defende, em seu estudo O Insólito em Guimarães Rosa e Borges, que o acontecimento sem explicação que irrompe na narrativa fantástica é o insólito. Tal estudo é o "resultado de sua tese orientada por Antonio Candido e defendida no ano de 1970. É importante notar que a pesquisadora gestava suas ideias aqui no Brasil quando Todorov escrevia seu livro que normatizou os estudos sobre literatura fantástica." (GAMA-KHALIL, 2013, p. 28).

Para Covizzi (1978, p. 26), o insólito é o "que carrega consigo e desperta no leitor o sentimento do inverossímil, incômodo, infame, incongruente, impossível, infinito, incorrigível, incrível, inaudito, inusitado, informal...". Segundo a autora, o insólito provoca perplexidade e excitação, e, se tratado como habitual, sua carga de estranheza aumenta. O insólito é, também, um fenômeno de inadequação que causa rupturas e deslocamentos nas relações de causa e consequência.

$\mathrm{O}$ vendedor, europeu, hesita perante o cachorro, e talvez o leitor do conto também o faça; entretanto, Maria dos Prazeres lida com esse fato naturalmente. Para ela, o cachorro que ri e que chora não é posto em causa ou negado. De acordo com Carpentier (2009), o insólito é tratado como natural e cotidiano na literatura fantástica latino-americana pelo fato de ela pertencer a uma vertente literária própria do Novo Mundo, o real maravilhoso, onde o insólito dá-se devido às características próprias do continente latino-americano, como inerente à sua identidade e cultura.

Carpentier (1987), ensaísta, novelista e músico cubano, nos fala sobre o movimento surrealista, no qual os artistas acreditavam que a arte deveria se libertar das exigências da lógica e da razão e ir além da consciência do dia-a-dia para poder expressar o inconsciente e a imaginação. A grande mola propulsora do surrealismo é o sonho. No entanto, para Carpentier, o surrealismo é fabricado de forma premeditada e calculada para produzir uma sensação de singularidade. Em contrapartida, o real maravilhoso latino-americano, "é aquele que encontramos em estado bruto, latente, onipresente em tudo que é latino-americano. Aqui o insólito é cotidiano, sempre foi cotidiano." (CARPENTIER, 1987, p. 125)

Sobre essa questão, podemos relacionar as ideias de Carpentier (1987, 2009) e Covizzi (1978), pois, de acordo com a autora, a literatura insólita escrita na América Latina difere-se do surrealismo por causa de nossa proximidade com as culturas primitivas e sua sobrevivência em nosso cotidiano, sendo o insólito tratado como um elemento cultural, e não só como uma inventividade artística, o que corrobora a dúvida sobre a realidade de tudo.

Ao final da negociação, Maria dos Prazeres resignou também aos verões sem árvores que fizessem sombra sobre sua tumba, pois as sombras estavam reservadas aos hierarcas do regime. Por querer se beneficiar do pagamento adiantado e à vista, as condições e fórmulas do contrato lhe eram supérfluas. Quando terminaram, o vendedor examinou a casa com "um olhar consciente e estremeceu como o hálito mágico de sua beleza. Tornou a olhar Maria dos Prazeres como se fosse a primeira vez." (MÁRQUEZ, 1992, p. 142). Depois das ações insólitas do cachorro, instaurou-se no vendedor um ar de fantasia. E, então, ele disse:

- Posso fazer uma pergunta indiscreta? - perguntou. Ela levou-o até a porta.

- Claro - disse -, desde que não seja a minha idade.

- Tenho a mania de adivinhar o ofício das pessoas pelas coisas que estão em suas casas, e aqui, para ser franco, não consigo - disse ele. - O que a senhora faz? Maria dos Prazeres respondeu morrendo de rir.

- Sou puta, filho. Ou já não dá mais para notar? O vendedor ficou vermelho.

- Sinto muito.

- Eu é que devia sentir - disse ela, tomando-o pelo braço para impedir que se esborrachasse contra a porta. - E toma cuidado! Não vá se arrebentar antes de me enterrar direitinho (MÁRQUEZ, 1992, p. 143).

Maria dos Prazeres fecha a porta, pega seu cãozinho e começa a limpá-lo. Enquanto o faz, ela canta, somando "sua bela voz africana aos coros infantis que naquele momento começavam a se ouvir na escola vizinha." (MÁRQUEZ, 1992, p. 143). Essa bela imagem de uma brasileira afrodescendente cantando evoca o que Carpentier (1987, p.121) fala sobre a mestiçagem da América Latina, que, por sua vez, evoca o espírito barroco: 
Toda simbiose, toda mestiçagem, engendra um barroquismo. O barroquismo americano se alia à 'criolledad', ao sentido do crioulo, à consciência adquirida pelo homem americano, seja filho do branco europeu, seja filho de negro africano, seja filho de índio nascido no continente - fato admiravelmente observado por Simón Rodriguez -, a consciência de ser outra coisa, de ser uma coisa nova, ser uma simbiose, de ser um crioulo; e o espírito crioulo já é por si mesmo um espírito barroco.

Três meses antes da visita do vendedor, Maria dos Prazeres havia tido um sonho, e, segundo sua interpretação o veredito era de que sua morte estava próxima. Desde então ela se sentiu mais ligada a Noi, aquela criatura de sua solidão. Ela havia previsto com muito cuidado a partilha póstuma de seus pertences e o destino de seu corpo que "naquele instante poderia morrer sem estorvar ninguém." (MÁRQUEZ, 1992, p. 143). Ela tinha se aposentado por vontade própria e havia escolhido o nobre e muito antigo povoado de Gràcia como refúgio final.

Maria dos Prazeres havia comprado o apartamento em ruínas, nas escadas faltavam degraus, além dos corredores úmidos e escuros, e não havia porteiro. Ela mandou reformar o banheiro e a cozinha, forrou as paredes, enfeitou o apartamento com cores alegres, levou móveis primorosos, e arcões de seda e brocados que comprou aos poucos em leilões secretos, pois foram roubados pelos fascistas das residências abandonadas pelos republicanos.

Ela não conhecia ninguém que morasse naquele edifício, a não ser um casal muito jovem com uma menina de nove anos que morava na porta em frente à dela. Maria tinha ainda um único vínculo com o passado, a amizade com o conde de Cardona que "continuou visitando-a na última sexta-feira de cada mês para jantar com ela e fazer um lânguido amor de sobremesa." (MÁRQUEZ, 1992, p. 144). Sua herança havia sido dividida nos mínimos detalhes, ditou de memória a lista minuciosa de seus bens aos amanuenses, com a lista completa dos herdeiros com seus endereços e profissões, o lugar que ocupavam no seu coração e o nome preciso de cada item em catalão medieval.

Após a visita do vendedor de enterros ela converteuse em mais um dos visitantes dominicais do cemitério:

A exemplo de seus vizinhos de túmulo semeou flores de quatro estações em seus canteiros, regava a grama recém-nascida e a igualava com a tesoura de podar até deixar como os tapetes da prefeitura, e familiarizou-se tanto com o lugar que acabou não entendendo como foi que no começo achava-o tão desolado.

Em sua primeira visita, o coração tinha dado um salto quando viu junto ao portal os três túmulos sem nome, e nem se deteve para olhá-los, porque a poucos passos dela estava o vigilante insone. Mas no terceiro domingo aproveitou um descuido para cumprir outro de seus grandes sonhos, e com batom escreveu na primeira lápide lavada pela chuva: Durruti. Desde então, sempre que pôde tornou a fazer isso, às vezes numa tumba, em duas ou nas três, e sempre com o pulso firme e o coração alvoroçado pela nostalgia (MÁRQUEZ, 1992, p. 145-146).

Com este ato de escrever e reescrever nas lápides o nome dos anarquistas, inferimos que Maria dos Prazeres participa dos ideais e das convicções dos revolucionários, ainda que seja pela solidariedade de seus sentimentos, e, assim, compreendemos que este ato também é uma forma de resistir e discordar da ditadura militar no Brasil, sua terra natal, que sofreu violências desmedidas com esse regime.

Apesar de estar muito ocupada com os preparativos para sua morte, a morte não mostra nenhum sinal de aproximação de Maria, que, pelo contrário, encontrava-se com mais ânimo para sobreviver aos enigmas de seus sonhos à medida que o calor aumentava e o ruído torrencial da vida entrava pelas janelas abertas. Todavia, ela havia treinado Noi para que ele distinguisse sua tumba no cemitério, empenhou-se em ensiná-lo a chorar sobre a sepultura, ainda que vazia, para que fizesse isso por costume após a sua morte. Ela levou-o várias vezes a pé de casa para o cemitério, a fim de que ele memorizasse a rota do ônibus das Ramblas, e certo dia, sentindo que ele estava bastante treinado, resolveu mandá-lo sozinho.

No domingo do ensaio final, às três da tarde, tirou do cãozinho o colete de primavera, em parte porque o verão era iminente e em parte para que chamasse menos a atenção, e deixou-o por sua conta. Viu como ele se afastava pela calçada de sombra com um trote ligeiro e o cuzinho apertado e triste debaixo da cauda alvoroçada, e conseguiu a duras penas reprimir os desejos de chorar, por ela e por ele, e por tantos e tão amargos anos de ilusões comuns, até que o viu dobrar rumo ao mar pela esquina da Calle Mayor. Quinze minutos mais tarde subiu no ônibus das Ramblas na vizinha praça de Lesseps, tentando enxerga-lo sem ser vista pela janela e enfim conseguiu vê-lo entre as molecagens dos meninos dominicais, distante e sério, esperando o sinal de pedestres do Paseo de Gràcia.

'Meu Deus', suspirou. 'Parece tão sozinho.' (MÁRQUEZ, 1992, p. 147).

Maria chegou ao panteão de Montjuich quase duas horas antes de Noi, e então ele apareceu na colina, "babando de fadiga e de calor, mas com ares de menino triunfante. Naquele momento, Maria dos Prazeres superou o terror de não ter ninguém que chorasse em sua tumba." (MÁRQUEZ, 1992, p. 148). 
No outono seguinte, o peso de seu coração aumentou, pois começou a perceber signos funestos que não conseguia decifrar. Para Maria, quase tudo à sua volta eram sinais inequívocos da morte: a conversa das vendedoras de pássaros das Ramblas, homens que não falavam de futebol nas bancas de livros, os silêncios dos mutilados de guerra que jogavam migalhas para os pombos, as luzes de Natal e a multidão de turistas que invadiu os cafés ao ar livre. Porém,

mesmo dentro da festa sentia-se a mesma tensão reprimida que precedeu os tempos em que os anarquistas se fizeram os donos da rua. Maria dos Prazeres, que havia vivido aquela época de grandes paixões, não conseguia dominar a inquietação, e pela primeira vez foi despertada na metade de um sonho por golpes de pavor. Uma noite, agentes da Segurança do Estado assassinaram a tiros na frente de sua janela um estudante que havia escrito no muro: Visca Catalunya lliure.

'Meu Deus", falou a si própria, assombrada, ‘é como se tudo estivesse morrendo comigo!'

Só havia conhecido uma ansiedade semelhante quando era muito pequena em Manaus, um minuto antes do amanhecer, quando os ruídos numerosos da noite cessavam de repente, as águas se detinham, o tempo titubeava, e a selva amazônica mergulhava num silêncio abismal que só podia ser igual ao da morte. (MÁRQUEZ, 1992, p. 147)

Novamente há referências ao regime franquista, do General Franco, por meio do qual foram impostas, entre tantas outras coisas, a censura e o extermínio da oposição. Visca Catalunya lliure, em língua catalã, que em espanhol seria Viva Cataluña libre, e, em português, Viva Catalunha livre, nos leva ao motivo da morte do estudante: durante o franquismo, o Estado pretendeu exterminar qualquer sinal identitário catalão.

No meio daquela tensão, como de costume, o conde de Cardona foi comer na casa de Maria dos Prazeres na última sexta-feira do mês. A visita era como um ritual, e os dois faziam tudo da mesma forma. O conde era discreto ao chegar no apartamento de Maria, pois queria proteger tanto a sua honra quanto a dela. Ela cozinhava os pratos favoritos dos catalães de estirpe de seus bons tempos e ele escutava fragmentos de óperas italianas no gramofone enquanto tomava aos poucos uma tacinha de vinho do porto.

Depois de jantarem e conversarem longamente, "faziam de cor um amor sedentário que deixava, nos dois, um sedimento de desastre.” (MÁRQUEZ, 1992, p. 150). E então, antes de partir, o conde deixava vinte e cinco pesetas em baixo do cinzeiro do quarto, pois esse era o preço de Maria dos Prazeres quando se conheceram em um hotel do Paralelo e essa era a única coisa que o tempo havia deixado intacta. Os dois não tinham quase nada em comum e nunca haviam se perguntado o motivo dessa amizade. O conde aconselhava Maria sobre o bom manejo de suas economias e havia indicado a ela o caminho de uma velhice decente no bairro de Gràcia, entretanto, quando estavam juntos, sentiam-se sozinhos, mas nenhum dos dois se atrevia a magoar os encantos do hábito de seus encontros.

Foi necessária uma comoção nacional para perceber o quanto haviam se odiado por tantos anos com tanta ternura. O conde estava escutando um dueto de amor no gramofone, quando ouviu uma rajada das notícias do rádio que Maria escutava na cozinha.

Aproximou-se com cuidado e escutou também. O general Francisco Franco, ditador eterno da Espanha, havia assumido a responsabilidade de decidir o destino final de três separatistas bascos que acabavam de ser condenados à morte. $\mathrm{O}$ conde exalou um suspiro de alívio.

- Então, vão fuzilá-los sem remédio - disse ele -, porque o Caudilho é um homem justo.

Maria dos Prazeres fixou nele seus ardentes olhos de cobra-real, e viu suas pupilas sem paixão atrás dos óculos de ouro, os dentes de rapina, as mãos híbridas de animal acostumado à umidade e às trevas. Do jeito que ele era.

- Pois rogue a Deus que não - disse -, porque se fuzilarem um só eu boto veneno na tua sopa.

$\mathrm{O}$ conde assustou-se.

- E por que isso?

- Porque eu também sou uma puta justa. (MÁRQUEZ, 1992, p. 151-152).

Covizzi (1978) assevera que as literaturas que florescem no subdesenvolvimento cultural adquirem lentamente a consciência nacional e universal, apresentando um olhar da margem, excêntrico, e então as literaturas latino-americanas deslocam-se das tradições europeias. Ricardo Piglia, escritor argentino, compartilha dessa opinião, afirmando que a visão de uma pessoa em um país central, com uma grande tradição cultural, difere totalmente da visão de alguém que se encontra à margem, às bordas da tradição cultural. Esse olhar da margem, excêntrico, é, para Piglia, o olhar de viés. "E este olhar enviesado nos daria uma percepção, talvez, diferente, específica. Há uma certa vantagem, às vezes, em não estar no centro. Olhar as coisas desde um lugar levemente marginal.” (PIGLIA, 20??, p. 1).

Maria dos Prazeres é, certamente, uma personagem marginal e excêntrica: mulher, afrodescendente, prostituta, estrangeira, velha, mística. Diante do ocorrido com o conde, ela teve a certeza de que o último ciclo de sua vida se encerrava. "Então mandou fazer uma lápide de anarquista, sem nome nem datas, e começou a dormir sem 
passar a tranca na porta para que Noi pudesse sair com a notícia se ela morresse durante o sono." (MÁRQUEZ, 1992, p. 152)

Um domingo, ao voltar do cemitério, encontrou a menina que morava na porta à sua frente. Acompanhou-a por vários quarteirões, falando com ela com um candor de avó, enquanto a menina brincava com Noi como se fossem velhos amigos. Na Plaza del Diamante, ofereceu-lhe um sorvete e perguntou se ela gostava de cachorros. A menina respondeu afirmativamente, e Maria fez a proposta que havia preparado há tempos: "- Se algum dia me acontecer alguma coisa, cuide do Noi - disse - com a única exceção de que nos domingos você o deixe livre, sem se preocupar. Ele vai saber o que fazer." (MÁRQUEZ, 1992, p. 152). A menina ficou feliz com a proposta, e Maria dos Prazeres também, com a sensação de ter vivido mais um sonho que amadureceu durante anos em seu coração.

Um dos principais recursos da arte é a singularização, que desautomatiza o nosso olhar, levando-nos a olhar de forma diferente e singular para os objetos vistos cotidianamente. Se a literatura em si já faz isso, a literatura fantástica exacerba essa noção, pois, por exemplo, na literatura insólita os objetos vistos por nós cotidianamente não guardam um compromisso estrito e explícito com a verdade do mundo prosaico (COVIZZI, 1978). Na narrativa em questão, podemos olhar de outra forma para essa mulher protagonista, Maria dos Prazeres, para a prostituição, para a morte e o medo da morte, para Noi, para os regimes ditatoriais, entre tantas outras opções que podem vir à tona a cada leitura.

Em uma tarde glacial de novembro, quando saía do cemitério, uma tormenta se precipitou. Maria dos Prazeres estava ensopada até os ossos, e mal conseguiu se abrigar nos portais de um bairro deserto, que parecia outra cidade, e que tornava a tormenta ainda mais pavorosa. Ela tentava aquecer Noi, que estava ensopado também, enquanto via os ônibus lotados passarem, os taxis vazios com as bandeiras abaixadas, "mas ninguém prestava atenção a seus sinais de náufrago." (MÁRQUEZ, 1992, p. 153). Repentinamente, quando até um milagre parecia impossível, um carro luxuoso, da cor do aço crepuscular, passou silenciosamente pela rua inundada, parou na esquina e voltou até onde Maria e Noi estavam.

Os vidros desceram por um sopro mágico, e o chofer se ofereceu para levá-la.

- Vou muito longe - disse Maria dos Prazeres com sinceridade. - Mas seria um grande favor me levar até mais perto.

- Diga aonde você vai - insistiu ele.

- A Gràcia - disse ela.

A porta abriu-se sem tocá-la.

- Está no meu caminho - disse ele. - Sobe.
No interior, que cheirava a remédio refrigerado, a chuva converteu-se num percalço irreal, a cidade mudou de cor, e ela sentiu-se num mundo alheio e feliz onde tudo estava resolvido de antemão. O condutor abria caminho através da desordem do trânsito com uma fluidez que tinha algo de magia. Maria dos Prazeres estava intimidada, não apenas pela sua própria miséria mas também pela do cãozinho digno de pena que dormia em seu regaço. (MÁRQUEZ, 1992, p. 154)

A partir desse trecho podemos observar a mudança de ânimo e a mudança de percepção do ambiente que Maria dos Prazeres tem desde o momento em que surge o carro, e mais ainda quando está dentro dele. Essas mudanças chegam a ser insólitas, como se tivessem algo de magia. Maria dos Prazeres elogia o carro, comparando-o a um transatlântico, e o motorista diz, em um catalão difícil, e depois em castelhano, que o carro não era dele, e que nem com seu salário da vida inteira poderia comprá-lo.

Maria o examina disfarçadamente e vê que era quase adolescente, "com o cabelo crespo e curto, e um perfil de bronze romano" (MÁRQUEZ, 1992, p. 154). Dificilmente ele era espanhol, tanto por seu físico, quanto por sua dificuldade com o idioma. Eles não voltaram a conversar durante o trajeto, mas ela percebeu que ele também a examinou várias vezes de soslaio, e condoeuse por continuar viva à sua idade. "Sentiu-se feia e compadecida, com o lenço de cozinha que havia posto na cabeça de qualquer jeito quando começou a chover, e o deplorável sobretudo de outono que não tivera a ideia de trocar porque estava pensando na morte." (MÁRQUEZ, 1992, p. 155)

Quando finalmente chegaram ao bairro de Gràcia a chuva já estava mais fraca e era noite. Ela pediu que ele a deixasse em uma esquina próxima, mas ele insistiu em levá-la até a porta, e também estacionou em cima da calçada para que ela descesse sem se molhar. Ela soltou Noi, saiu do carro da melhor forma que seu corpo permitiu, e,

Quando se virou para agradecer encontrou-se com um olhar de homem que deixou-a sem fôlego. Manteve o olhar por um instante, sem entender direito quem esperava o quê, nem de quem, e então ele perguntou com uma voz decidida:

- Subo?

Maria dos Prazeres sentiu-se humilhada.

- Agradeço muito o favor de me trazer - disse -, mas não permito que caçoe de mim.

- Não tenho nenhum motivo para caçoar de ninguém disse ele em castelhano com uma seriedade terminante. - E muito menos de uma mulher como a senhora.

Maria dos Prazeres havia conhecido muitos homens como aquele, salvara do suicídio muitos outros mais atrevidos que aquele, mas nunca em sua longa vida 
tivera tanto medo de decidir. Ouviu-o insistir sem o menor indício de mudança na voz:

- Subo?

Ela afastou-se sem fechar a porta do automóvel e respondeu em castelhano para ter certeza de ser entendida.

- Faça o que quiser (MÁRQUEZ, 1992, p. 155-156).

Então ela entrou no saguão mal iluminado de seu prédio e começou a subir a escada com os joelhos trêmulos, "sufocada por um pavor que só acreditava possível no momento de morrer." (MÁRQUEZ, 1992, p. 156). Já em frente a seu apartamento, de tão ansiosa não conseguia encontrar as chaves na bolsa, ouviu a batida das duas portas do automóvel na rua. Ao sentir os primeiros passos nos degraus soltos da escada,

temeu que seu coração fosse arrebentar. Numa fração de segundo voltou a examinar por completo o sonho premonitório que havia mudado sua vida durante três anos e compreendeu o erro de sua interpretação.

'Deus meu', disse assombrada. 'Quer dizer que não era a morte!'

Encontrou finalmente a fechadura, ouvindo os passos contados na escuridão, ouvindo a respiração crescente de alguém que se aproximava tão assustado quanto ela no escuro, e então compreendeu que havia valido a pena esperar tantos e tantos anos, e haver sofrido tanto na escuridão, mesmo que tivesse sido só para viver aquele instante (MÁRQUEZ, 1992, p. 156-157).

O desfecho do conto é bastante insólito, pois, esperávamos pela morte de Maria dos Prazeres, e as águas agitadas e pesadas da tormenta que pareciam recebê-la em sua intimidade e encaminhá-la para a morte, como a água da enchente de Manaus, não o fazem, e a carregam para algo totalmente diferente. O poeta brasileiro Carlos Drummond de Andrade escreveu que o amor é primo da morte, e da morte vencedor. Será que Maria dos Prazeres encontra, nesse rapaz, o amor? Será que ele lhe traz a paixão que talvez nunca tenha sentido?

Se é amor e/ou paixão, não podemos afirmar, visto que a ambiguidade permanece nesta narrativa fantástica. Todavia, acreditamos que Maria dos Prazeres, no desfecho do conto, é tomada pela vida e pela vontade de viver. Na cerimônia de entrega do Prêmio Nobel de Literatura, outorgado a ele mesmo, García Márquez disse, em seu discurso intitulado "A solidão da América Latina", que

diante da opressão, do saqueio e do abandono, nossa resposta é a vida. Nem os dilúvios, nem as pestes, nem a fome, nem os cataclismos, nem mesmo as guerras eternas através dos séculos e séculos conseguiram reduzir a vantagem tenaz da vida sobre a morte (MÁRQUEZ, 2011, p. 27-28).
Não devemos esquecer que durante esse discurso, em Estocolmo na Suécia, 8 de dezembro de 1982, García Márquez rompeu com a tradição de toda a história dos prêmios Nobel ao apresentar-se vestido com uma típica vestimenta caribenha ao invés do rigoroso fraque, falando do lugar da margem, totalmente de acordo com a proposta de Piglia para o novo milênio.

\section{Referências}

BACHELARD, Gaston. A água e os sonhos: ensaio sobre a imaginação da matéria. São Paulo: Martins Fontes, 1997.

CANDIDO, Antonio; GOMES, Paulo Emílio Salles; PRADO, Décio de Almeida; ROSENFELD, Anatol. A personagem de ficção. São Paulo: Perspectiva, 2009.

CARPENTIER, Alejo. Prólogo. In: CARPENTIER, Alejo. $O$ reino deste mundo. São Paulo: Martins Fontes - selo Martins, 2009. p. 7-12.

CARPENTIER, Alejo. A literatura do maravilhoso. São Paulo: Editora Revista dos Tribunais, Edições Vértice, 1987.

COVIZZI, Lenira Marques. Uma ficção insólita num mundo insólito. In: COVIZZI, Lenira Marques. O insólito em Guimarães Rosa e Borges. São Paulo: Editora Ática, 1978, p. 25-47.

FURTADO, Filipe. A Construção do Fantástico na Narrativa. Lisboa: Livros Horizonte, 1980.

FURTADO, Filipe. Fantástico (Modo). E-dicionário de termos literários (EDTL). Coord. Carlos Ceia. [20??]. ISBN: 98920-0088-9. Disponível em: < http://edtl.fcsh.unl.pt/businessdirectory/6033/fantastico-modo/>. Acesso em 25 jan. 2017.

GAMA-KHALIL, Marisa Martins. A literatura fantástica: gênero ou modo? Terra roxa e outras terras. Londrina, v. 26, p. 18-31, dez. 2013.

HUTCHEON, Linda. Poética do pós-modernismo: história, teoria, ficção. Rio de Janeiro: Imago Ed., 1991.

MÁRQUEZ, Gabriel García. Doze contos peregrinos. Rio de Janeiro: Record, 1992.

MÁRQUEZ, Gabriel García. Eu não vim fazer um discurso. Rio de Janeiro: Record, 2011.

PIGLIA, Ricardo.Uma proposta para o novo milênio. [20??]. Disponível em <http://chaodafeira.com/wp-content/ uploads/2015/06/cad02.pdf>. Acesso em: 23 abr. 2017.

SIMIONI, Rafael Lazzarotto. Arquivo, história e memória: possibilidades de diálogo entre Luhmann e Foucault. Lua Nova, São Paulo, v. 97, p. 173-190, 2016.

TODOROV, Tzvetan. Introdução à literatura fantástica. São Paulo: Perspectiva, 2004.

VIEIRA, Felipe de Paula Góis. América Violentada: Identidade, Exílio e Ditadura na obra Doze Contos Peregrinos de Gabriel García Márquez. História Social, v. 18, p. 117-136, 2010.

Recebido: 24 de abril de 2017

Aprovado: 01 de outubro de 2017

Contato:

Bethânia Martins Mariano <bmmariano@outlook.com> ORCID: https://orcid.org/0000-0002-9471-9862 